\title{
Assessment of awareness of mycotoxins infections in stored maize (Zea mays L.) and groundnut (arachis hypogea L.) in Kilosa District, Tanzania
}

\author{
K. S. Magembe ${ }^{1}$, M. W. Mwatawala², D. P. Mamiro² and E. E. Chingonikaya ${ }^{1}$
}

\begin{abstract}
Background: Surveys were conducted to determine awareness of mould infection in maize and groundnut in Kilosa District, Eastern Central Tanzania, between August and October 2010. Four villages of Msingisi, Rudewa-Batini, Mamoyo and Mkalama were surveyed. We sampled maize from each household for mycotoxins contamination after nine months of storage. A questionnaire was administered to heads of 72 selected households in the study area. Principal component analysis (PCA) was used to check factor dimensionality. The differences in mean total score of knowledge and awareness between the demographic and socio-economic factors were determined by $t$-test. Measurements of association were carried by Chi-square test (x2), while ordinal logistic regression analysis was used to examine the correlations between social variables and awareness of mould infection.

Results: We found high levels of fumonisins in maize that ranged from 70.46 to 213.15. Aflatoxin levels in groundnuts ranged from 72.97 to 195.17. Result showed that $97 \%$ of respondents were not aware of mould infection in stored maize and groundnuts. The mean score of mould infections awareness of females $(1.7273 \pm 0$. 45055) was significantly higher than that of males (1.5714 \pm 13.7$)$. Awareness of mould infection was high among educated (mean score 1.9231.3 \pm 0.31470 ) than the less educated people (mean score $1.8913 \pm 0.27175$ ). Results revealed significant association between awareness of mould infection with age $(p=0.006)$, education $(p=0.039)$, marital status $(p=0.012)$, gender (0.037) and income $(p=0.044)$.
\end{abstract}

Conclusion: Campaigns are needed to improve awareness of mould infection in Kilosa District, Tanzania.

Keywords: Maize, Groundnut, Awareness, Mould, Infections, Knowledge, Gender, Income, Age, Tanzania

\section{Background}

Fumonisins and aflatoxins are the most important mycotoxins in Africa and other developing countries in the tropics (WHO 2006). Mycotoxins cause several human and animal diseases (Bhat 2008; O'Riordan and Wilkinson 2008), including jaundice and liver cancer (Jolly et al. 2007).

A report by Jolly et al. (2008) showed that over 100 U\$D billion of exported commodities were susceptible to mycotoxin contamination all over the world. Mycotoxins

\footnotetext{
* Correspondence: mwatawala@yahoo.com

${ }^{2}$ Department of Crop Science and Horticulture, Sokoine University of

Agriculture, P.O. Box 3005, Morogoro, Tanzania

Full list of author information is available at the end of the article
}

contamination attracts worldwide attention due to the huge economic losses incurred and their impact on human, domestic animals and trade (Wu, 2006; Chilaka, et al. 2012). Mycotoxins contaminate many agricultural products including maize (Zea mays L.) and groundnut (Arachis hypoea L.) as well as milk, meat and eggs (Bankole et al. 2006; Kumar et al. 2008; Okello et al. 2010). Human beings and animals contact mycotoxins by ingesting contaminated foods and feeds respectively.

Diseases caused by mycotoxins are much common in developing countries. Dietary exposure to mycotoxins can result in serious health affect both acute and chronic. Ranging from sudden death to deleterious effects upon the central nervous, induction of hepatocellular carcinoma, effects 
on the cardiovascular, reproductive, pulmonary, and gastrointestinal systems to mention few (Burger et al. 2013; Suleiman et al. 2013). Most developing countries are in the tropics, where high temperatures and relative humidity, poor aeration in stores, insects and rodents damage favour accumulation of mycotoxins in agricultural produce (Hell and Mutegi, 2011). Consequently, most of the reported mycotoxin - poisoning incidences occurred in the subSaharan Africa (Bankole et al. 2006) where facilities for monitoring contamination were non-existent in developing (Kumar and Popat 2010).

Health risks associated with mycotoxins can be reduced through awareness campaigns (Strosnider et al. 2006). High levels of mycotoxins were reported in Tanzania (see for example Kimanya et al. 2008; Kimanya et al. 2010, 2014; Kamala et al. 2016). The incidence and extent of fumonisins contamination of home-stored maize for human consumption in Tanzania was reported with levels up to $11.048 \mathrm{mg} / \mathrm{kg}$ (Kimanya et al. 2008), and levels up to $2.283 \mathrm{mg} / \mathrm{kg}$ in maize based complementary food (Kimanya et al., 2014). According to Amri and Lenoi (2016), the percentage of sweet potato samples samples which tested positive for aflatoxins in Kahama Ditrict was $36 \%$ with contamination in ranges from $10.49 \mu \mathrm{g} / \mathrm{kg}$ ) to $75.12 \mu \mathrm{g} / \mathrm{kg}$. The aflatoxin $\mathrm{B}_{1}$ $\left(\mathrm{AFB}_{1}\right)$ contamination in sweet potato was the most prevalent with concentration of $21.23 \mu \mathrm{g} / \mathrm{kg}$ followed by aflatoxin $G_{1}\left(A F G_{1}\right)$ with concentration of $10.38 \mu \mathrm{g} / \mathrm{kg}$. Fumonisin $B_{1}\left(F_{1}\right)$ ranged from 29.34-628.78 mg/kg, with an average of mean $44.69 \mathrm{mg} / \mathrm{kg}$.

A study by Kimanya et al. (2014) reported that in Rombo District, North Eastern Tanzania, thirteen (32\%) of the 41 children consumed maize flour with detectable aflatoxin levels that ranged from 0.11 to $386 \mathrm{mg} / \mathrm{kg}$ ), resulting in exposures that ranged from 1 to786 ng/kg bw/day. All these children exceeded the aflatoxins exposure of $0.017 \mathrm{ng} / \mathrm{kg} \mathrm{BW/day.} \mathrm{Thirty} \mathrm{four} \mathrm{(83} \mathrm{\% )} \mathrm{con-}$ sumed maize flour with detectable fumonisins levels that ranged from 63 to $2284 \mathrm{mg} / \mathrm{kg}$, and resulted in respective exposure range of $0.19-26.37 \mathrm{mg} / \mathrm{kg} \mathrm{BW} /$ day. In another study, Magoha et al. (2016) surveyed food intake and estimated the risk of exposures to aflatoxin and fumonisin mycotoxins for infants less than 6 months of age in Northern Tanzania. According to the study, $57 \%$ of 67 maize flour samples contained detectable aflatoxins, that ranged from $0.33-69.47 \mu \mathrm{g} \mathrm{kg} \mathrm{kg}^{-1}$ and $31 \%$ contained detectable fumonisins that ranged from 48 to1224 $\mu \mathrm{g} \mathrm{kg}^{-1}$. The study by Magoha et al. (2016) further reported that, infants who consumed contaminated flours, aflatoxin exposure ranged from 0.14 to $120 \mathrm{ng} \mathrm{kg}$ $(-1)$ body weight (BW) per day, and fumonisin exposure ranged from 0.005 to $0.88 \mu \mathrm{g} \mathrm{kg}(-1) \mathrm{BW}$ per day. These ranges are all above the health concern level of $0.017 \mathrm{ng} \mathrm{kg}(-1) \mathrm{BW}$ per day as recommended by the
European Food Safety Agency). A study by Kamala et al. (2016) in various agro-ecological zones of Tanzania found that $45 \%$ and $85 \%$ of maize samples were positive for aflatoxins and fumonisins respectively, with levels that ranged from 0.1 to $269 \mu \mathrm{g} \mathrm{kg}-1$ for aflatoxins and from 49 to $18,273 \mu \mathrm{g} \mathrm{kg}-1$ for fumonisins.

Potential losses and hazards due to mycotoxins can be reduced by promoting education and awareness on postharvest handling of these products. Farmers can be important partners in educating the masses on the harmful effects mycotoxins. However, the level of awareness of mould infections in stored maize and groundnuts and the risk of ingestion among farmers in many parts of Tanzania, including Kilosa District is not known. This study assessed the awareness and knowledge of mycotoxins in stored maize and groundnut and the risk of its ingestion among farmers in Kilosa District, Tanzania.

\section{Methods \\ Surveys and data collection}

A descriptive cross-sectional study on assessment of awareness of mould infections in stored maize and groundnuts in Kilosa District was carried out between August and October, 2010. Studies were carried out in Mamoyo, Rudewa-Batini, Mkalama and Msingisi villages (see Table 1). The District is located in semi arid, sub humid parts of Tanzania. Farmers in the study villages grow maize and groundnut. We obtained lists of farmers who grew and stored maize and groundnuts from village government records. We then randomly selected the farmers for inclusion into the survey.

\section{Determining mycotoxin levels in maize and groundnut}

Shelled maize (variety TMV -1) and groundnuts (local variety "Chusa") were collected and stored in eighteen households in each village, starting October 2010. Batches of $2 \mathrm{kgs}$ of each crop were kept in small re-used, polypropylene woven bags (locally known as "viroba", mostly from Azania Polybag Ltd. and Azam Polysack Ltd., Tanzania). We did not add any protectant to the bags. Samples of $0.5 \mathrm{~kg}$ were drawn from each bag (from each household) using a sampling spear (Seedburo Equipment, Chicago, USA) after nine months of storage. A sample was placed in labeled paper bags before they were sent to the Tanzania Food and Drug Authority (TFDA) laboratories (ISO/IEC 17025:2005 Accredited). Aflatoxin $\mathrm{B}_{1}\left(\mathrm{AF} \mathrm{B}_{1}\right)$ analyses were performed using a HPLC instrument consisting of two chromatographic pumps, sampling system, and fluorescence detector (HPLC-FLD). Methods described by Abbas et al. (2002) and Trucksess et al. (1991) were followed. Only $\mathrm{AFB}_{1}$ was considered for data analysis, being the most toxic and almost always dominant aflatoxin. 
Table 1 Description of four surveyed villages in Kilosa District, Tanzania

\begin{tabular}{|c|c|c|c|c|c|c|}
\hline Location & Latitude (South) & Longitude (East) & $\begin{array}{l}\text { Elevation } \\
\text { (m. a. s. I) }\end{array}$ & $\begin{array}{l}\text { Average Temperature } \\
\left({ }^{\circ} \mathrm{C}\right) \text { (Annual) }\end{array}$ & $\begin{array}{l}\text { Average Relative } \\
\text { Humidity (\%) }\end{array}$ & $\begin{array}{l}\text { Total Rainfall } \\
(\mathrm{mm})\end{array}$ \\
\hline Mamoyo & $\mathrm{S} 06.83447^{\circ}$ & E037.04475 & 506.4 & 26.5 & 93.3 & 1,400 \\
\hline Rudewa-Batini & $\mathrm{S} 06.69351^{\circ}$ & E037.12182 & 428.1 & 25.4 & 90.2 & 1,300 \\
\hline Msingisi & $\mathrm{S} 06.21324^{\circ}$ & $\mathrm{E} 036.86646^{\circ}$ & 1,357 & 31.9 & 76.5 & 850 \\
\hline Mkalama & $\mathrm{S} 06.08692^{\circ}$ & $\mathrm{E} 036.85160^{\circ}$ & 1,270 & 30.1 & 66.2 & 800 \\
\hline
\end{tabular}

Fumonisins $\left(\mathrm{FB}_{1}\right)$ analyses were also carried out in TFDA laboratories where a sample of $250 \mathrm{~g}$ of dry-shelled maize samples were mixed and ground using a Romer Mill and homogenised and stored at $-20^{\circ} \mathrm{C}$ until analysis. Samples were cleaned up by Multisep 211 column for quantification and fumonisins were detected by the highperformance liquid chromatography with fluorescence detection (HPLC-FLD). We followed methods described by Abbas et al. (2002). Only $\mathrm{FB}_{1}$ were considered for data analysis, being the most toxic and most dominant. We measured and averaged the mycotoxin levels for each crop per village.

\section{Farmers' awareness on mycotoxins contamination in maize and groundnuts}

A semi-structured self administered questionnaire was used to collect data on respondents' socio demographic (age, gender and marital status) and socioeconomic characteristics (household income), awareness and knowledge of mould infection in stored maize and groundnuts and the risk of its ingestion. Initially, the questionnaire was pre-tested to ascertain its reliability. A total of 72 farmers were interviewed. A number of statements were created to determine knowledge and awareness of mould infection in stored maize. The statements were measured on a threepoint Likert-scale $(0=$ Do not know, $1=$ Not sure and 2 = I know). The statements were created by referring to literature on mycotoxins occurrence in Tanzania.

Principal component analysis (PCA) was performed on three constructs Likert-scales to check factor dimensionality. Awareness and knowledge were extracted from a factor analysis conducted on each set of statements defining each one in particular. A scree test with varimax rotation was used to obtain more interpretable statements (Hatcher 1994). Statements with factor loading of 0.40 or greater were retained for further analysis. Chisquare $(x 2)$ test was used to explore associations between variables of interest at $5 \%$ level of significance.

\section{Data analysis}

The differences in mean total score of knowledge and awareness on mould infection between the demographic and socio-economic factors were determined using inferential statistics ( $t$-test). Measurements of association were carried by Chi-square test $(\chi 2)$ for categorical variables. Chi-square test was used to see if significant relationships exist between the total knowledge and awareness score and the variables. Ordinal logistic regression analysis was used to examine the correlations between gender, education level, marital status and income level compared with knowledge scores of respondents. Statistical significance was set at 0.05 . The p-value of less than 0.05 was considered significant. Data were analyzed using SPSS version 14 statistical software.

\section{Results}

The levels of fumonisins $B_{1}\left(F B_{1}\right)$ in stored maize and aflatoxin $B_{1}\left(A F B_{1}\right)$ in stored groundnuts in the study area We determined mean mycotoxins per each studied village. All the collected samples were contamined by $\mathrm{FB}_{1}$ after nine months of storage. $\mathrm{FB}_{1}$ levels ranged from 70.46 to 213.15 . The means for each village are shown in Table 2. Samples from Mamoyo village had highest mean level of $\mathrm{FB}_{1}$ (Table 2).

Mean $\mathrm{AFB}_{1}$ samples in groundnuts are shown in Table 3. All groundnut samples were contaminated by $\mathrm{AFB}_{1}$ after nine months of storage. Highest levels of $\mathrm{AFB}_{1}$ were found in samples collected from Mamoyo village. $\mathrm{AFB}_{1}$ levels in the studied villages ranged from 72.97 to 195.17 (Table 3).

\section{Farmers awareness of mould infection in maize and groundnuts}

The consistency of the questionnaire is indicated by the Cronbach's alpha of 0.745 from the 8-item questionnaire

Table 2 Mean fumonisin $B_{1}(\mu \mathrm{g} / \mathrm{kg})$ in stored maize for the four villages surveyed in Kilosa District

\begin{tabular}{|c|c|c|c|c|c|c|c|}
\hline \multirow[t]{2}{*}{ Village } & \multirow[t]{2}{*}{$\begin{array}{l}\text { No. of } \\
\text { samples }\end{array}$} & \multirow[t]{2}{*}{ Mean } & \multirow[t]{2}{*}{$\begin{array}{l}\text { Std. } \\
\text { Err }\end{array}$} & \multicolumn{2}{|c|}{$\begin{array}{l}95 \% \text { Confidence } \\
\text { Interval for Mean }\end{array}$} & \multirow[t]{2}{*}{ Min } & \multirow[t]{2}{*}{ Max } \\
\hline & & & & $\begin{array}{l}\text { Lower } \\
\text { Bound }\end{array}$ & $\begin{array}{l}\text { Upper } \\
\text { Bound }\end{array}$ & & \\
\hline Mamoyo & 18 & 165.75 & 7.42 & 150.09 & 181.4096 & 70.95 & 213.15 \\
\hline $\begin{array}{l}\text { Rudewa- } \\
\text { Batini }\end{array}$ & 18 & 162.30 & 6.63 & 148.31 & 176.2869 & 75.46 & 188.93 \\
\hline Msingisi & 18 & 152.18 & 7.12 & 137.36 & 167.3920 & 70.83 & 195.55 \\
\hline Mkalama & 18 & 151.28 & 7.28 & 135.92 & 166.6349 & 63.26 & 207.97 \\
\hline Total & 72 & & & & & & \\
\hline
\end{tabular}


Table 3 Mean aflatoxin $B_{1}(\mu \mathrm{g} / \mathrm{kg})$ level in stored groundnuts for the four villages surveyed in Kilosa District

\begin{tabular}{|c|c|c|c|c|c|c|c|}
\hline \multirow[t]{2}{*}{ Village } & \multirow[t]{2}{*}{$\begin{array}{l}\text { No. of } \\
\text { samples }\end{array}$} & \multirow[t]{2}{*}{ Mean } & \multirow[t]{2}{*}{$\begin{array}{l}\text { Std. } \\
\text { Err }\end{array}$} & \multicolumn{2}{|c|}{$\begin{array}{l}95 \% \text { Confidence } \\
\text { Interval for Mean }\end{array}$} & \multirow[t]{2}{*}{ Min } & \multirow[t]{2}{*}{ Max } \\
\hline & & & & $\begin{array}{l}\text { Lower } \\
\text { Bound }\end{array}$ & $\begin{array}{l}\text { Upper } \\
\text { Bound }\end{array}$ & & \\
\hline Mamoyo & 18 & 148.84 & 6.03 & 136.13 & 161.55 & 83.20 & 195.05 \\
\hline $\begin{array}{l}\text { Rudewa- } \\
\text { Batini }\end{array}$ & 18 & 146.06 & 6.11 & 133.18 & 158.95 & 74.40 & 184.55 \\
\hline Msingisi & 18 & 133.89 & 6.89 & 119.35 & 148.42 & 72.97 & 195.17 \\
\hline Mkalama & 18 & 132.46 & 4.98 & 121.95 & 142.97 & 81.29 & 175.49 \\
\hline Total & 72 & & & & & & \\
\hline
\end{tabular}

completed by respondents (Table 2). Additionally, the Kaiser-Meyer-Olkin (KMO) value 0.688 and the Bartlett's Test $(\mathrm{p}<0.000)$ confirmed the suitability of data. Two statements (with Eigen values exceeding 1 and factor loading above 0.4) were identified as underlying factors of the eight (8) statements (Table 2). In total, these factors accounted for $68.5 \%$ of the variance in the data. The measures of overall goodness of fit of the model were acceptable. The $\chi^{2}$-statistic was 84.908 for $28^{\circ}$ of freedom $(p<$ $0.005)$. All factor loadings were statistically significant at the $95 \%$ confidence level. The final items defining the scales of individuals' awareness of mould infection are presented in Table 4.

Our study revealed that forty nine percent (49\%) of the respondents identified mycotoxin as a "mould that attacks maize and groundnuts." Furthermore, $57 \%$ of the respondents could not differentiate mold infestation and damage due to other causes (Table 5).

Table 4 Varimax rotated factor structure of the eight items of awareness and knowledge of mould infection in stored maize and groundnuts

\begin{tabular}{lcl}
\hline Statements/Questions & $\begin{array}{c}\text { Factor } \\
\text { Loadings }\end{array}$ & $\begin{array}{l}\text { Cronbach's } \\
\text { alpha }\end{array}$ \\
\hline 1. Can you identify spoilt maize/groundnuts? & 0.531 & 0.745 \\
2. Do you sort your crops after harvest? & 0.548 & \\
3. Do you know how to identify well dried & 0.661 & \\
pods/ grain? & & \\
4. Do you clean the storehouse before & 0.527 \\
storage? & \\
$\begin{array}{l}\text { 5. Aflatoxins and fumonisins cause liver cancer } \\
\text { in human being }\end{array}$ & 0.696 \\
$\begin{array}{l}\text { 6. Have you heard of the word mycotoxins } \\
\text { before? }\end{array}$ & 0.783 \\
7. Do you know the right time to harvest your \\
crops?
\end{tabular}

Table 5 Identification of awareness and knowledge on mould infection in maize and groundnuts

\begin{tabular}{|c|c|c|c|}
\hline Statements & Response & $\mathrm{N}$ & $\begin{array}{l}\text { Percentage } \\
(\%)\end{array}$ \\
\hline \multirow{2}{*}{$\begin{array}{l}\text { Can you identify spoilt maize/ } \\
\text { groundnuts? }\end{array}$} & Yes & 32 & 44.4 \\
\hline & No & 40 & 55.6 \\
\hline \multirow[t]{5}{*}{ How do you identify spoilage? } & Insect rot & 11 & 15.3 \\
\hline & Rot & 35 & 48.6 \\
\hline & Discoloration & 7 & 9.7 \\
\hline & Insects & 15 & 20.8 \\
\hline & $\begin{array}{l}\text { Visible water vapour } \\
\text { on grains }\end{array}$ & 4 & 5.6 \\
\hline \multirow{2}{*}{$\begin{array}{l}\text { Do you sort your crops after } \\
\text { harvest? }\end{array}$} & Yes & 36 & 50.0 \\
\hline & No & 36 & 50.0 \\
\hline \multirow{6}{*}{$\begin{array}{l}\text { What do you do with spoilt } \\
\text { grains? }\end{array}$} & Throw them away & 25 & 34.7 \\
\hline & $\begin{array}{l}\text { Feeding livestock/ } \\
\text { poultry }\end{array}$ & 13 & 18.1 \\
\hline & Making local brew & 5 & 6.9 \\
\hline & Re-dry and consume & 13 & 18.1 \\
\hline & Sell to the market & 10 & 13.9 \\
\hline & $\begin{array}{l}\text { Throw and gave } \\
\text { them to livestock } \\
\text { poultry }\end{array}$ & 6 & 8.3 \\
\hline \multirow{3}{*}{$\begin{array}{l}\text { What causes spoilage in maize } \\
\text { and groundnuts }\end{array}$} & Poor drying & 36 & 50.0 \\
\hline & $\begin{array}{l}\text { Heaping maize on } \\
\text { floor }\end{array}$ & 28 & 38.9 \\
\hline & $\begin{array}{l}\text { Use of expired } \\
\text { pesticides }\end{array}$ & 8 & 11.1 \\
\hline \multirow{2}{*}{$\begin{array}{l}\text { Do you know how to identify } \\
\text { well-dried pods/ grain? }\end{array}$} & Yes & 31 & 43.1 \\
\hline & No & 41 & 56.9 \\
\hline \multirow{2}{*}{$\begin{array}{l}\text { Do you clean the storehouse } \\
\text { before storage? }\end{array}$} & Yes & 34 & 47.2 \\
\hline & No & 38 & 52.8 \\
\hline \multirow{2}{*}{$\begin{array}{l}\text { Aflatoxins and fumonisins cause } \\
\text { liver cancer in human being }\end{array}$} & Yes & 24 & 66.7 \\
\hline & No & 48 & 33.3 \\
\hline \multirow{2}{*}{$\begin{array}{l}\text { Have you heard of the word } \\
\text { mycotoxins before? }\end{array}$} & Yes & 2 & 97.2 \\
\hline & No & 70 & 2.8 \\
\hline \multirow{2}{*}{$\begin{array}{l}\text { Do you know the measures to } \\
\text { be taken for controlling fungi } \\
\text { and spoilage in store }\end{array}$} & Yes & 26 & 36.1 \\
\hline & No & 46 & 63.9 \\
\hline \multirow{2}{*}{$\begin{array}{l}\text { Do you know the right time to } \\
\text { harvest your crop? }\end{array}$} & Yes & 31 & 43.1 \\
\hline & No & 41 & 56.9 \\
\hline
\end{tabular}

Source: Survey data, 2010

Respondents mentioned various causes of contamination that included poorly-dried and/or wet maize (50\%), heaping maize on floor (38.9\%) and use of expired pesticides $(11 \%)$. Of all respondents, $66.7 \%$ were not aware of the health hazards caused by mycotoxins. Results further showed that $63.9 \%$ of respondents did not know measures for controlling fungi and spoilage in store while $36.1 \%$ of respondents were able to tell the 
presence of mycotoxins by the "discoloration of the maize". Mouldiness and wetness were other indicators listed by all $72(100 \%)$ farmers. Insects damage was mentioned by $15.3 \%$ of respondents as an indicator of mycotoxins contamination (Table 5).

It was revealed by the present study that, $47.2 \%$ of respondents dry their grains before storage either as cobs or grain as a precaution against infection. Respondents used infected grains in various ways, including feeding livestock/ poultry (18.1 \%), disposal (34.7\%), making local brew (6.9\%), re-redrying and consuming (18.1\%), selling (13.9\%) or both disposing and feeding livestock/ poultry $(8.3 \%)$.

\section{Association between demographic and socio-economic factors and knowledge on fungal contamination in food crops}

The Ordinal logistic regression analysis showed association between age, education level, gender, marital status and household income compared with mould infections awareness score (Table 6). The odds ratio of 1.805 indicated that respondents with low level of education (below secondary level) were 1.805 times more likely to have low level of awareness and knowledge than those who had higher education.

Significant differences were also observed between income groups and marital status (Table 6). The odds ratio of 0.936 indicated that respondents who had income of more that 66.7 USD were 0.936 times more likely to have high of awareness on mould infection than those who had income of less than 66.7 USD. The odds ratio of 3.665 indicated that respondents who were living together (married) were 3.665 times more likely to have more level of awareness and knowledge on mould

Table 6 Odds ratios (95\% Cl) from ordinal logistic regression (OLR) of awareness and knowledge level as a function of demographic and socio-economic variables $(n=72)$

\begin{tabular}{lll}
\hline Variable $^{\mathrm{b}}$ & Odds Ratio $(95 \% \mathrm{Cl})$ & $p$-value \\
\hline Age & $0.104(0.029-0.178)$ & $0.006^{* *}$ \\
Education & $1.805(0.090-3.521)$ & $0.039^{*}$ \\
Marital Status & $3.665(0.791-6.539)$ & $0.012^{*}$ \\
Gender & $1.869(0.112-3.626)$ & $0.037^{*}$ \\
Income & $0.936(0.023-1.848)$ & $0.044^{*}$ \\
Chi-square $\left(X^{2}\right)=61.068$, Sig. & $<0.0001$ & \\
Pseudo R-Square & & \\
Cox and Snell & 0.572 & \\
Nagellkerne & 0.767 & \\
McFadden & 0.620 & \\
\hline
\end{tabular}

*Significant different at $p<0.05$ and ** Significant different at $p<0.01$

${ }^{b}$ Variables are coded either 1 or 0

c Pseudo R-Square measures the strength of associations between variables infection than those who were living single (being single, divorced or widow).

Similarly, the odds ratio of 0.104 indicated that respondents with age of less than 35 years were 0.104 times more likely to have low level of awareness on mould infection than those who had age of 35 years and above. The mean score of moldy awareness of females $(1.7273 \pm 0.45055)$ was significantly higher than that of males (1.5714 \pm 13.7000$)$. Similarly, the mean score of more educated people $(1.9231 .3 \pm 0.31470)$ was significantly higher than that of less educated people (1.8913 \pm $0.27175)$. Significant differences were also observed between income groups and marital status. Table 7 shows the description of model's variable used in the study and Table 8 shows the independent $t$-test on demographic and socio-economic characteristics on knowledge of mould infections in stored maize and groundnuts.

\section{Discussion}

Based on WHO standards, the majority of the samples in the study villages (100\%) were not safe for consumption because they exceeded $20 \mu \mathrm{g} / \mathrm{kg}$. The results of the present study indicate that the incidence and level of mycotoxins contamination in stored maize and groundnuts is quite high in Kilosa District. Poor harvesting and post harvest handling practices are the major factors that promote mycotoxins contaminations. In most studies villages farmers do not have means to determine optimum levels of moisture for stored grains and nuts. Maize and groundnuts are stored in polythene bags. High humidity (in poly bags) promotes moulds contamination (Kimanya et al., 2009). Farmers in studied villages do not sort commodities to remove attacked nuts and seeds. Most farmers place poly bags with commodities on the floor, exposing them to various forms of moisture. Maize is is shelled by beating cobs in a bag, which damages kernels and expose them to fungal attacks. Furthermore,

Table 7 Description of model's variable

\begin{tabular}{|c|c|c|}
\hline & Dependent variable & Categories \\
\hline \multirow[t]{2}{*}{ Awareness } & $\begin{array}{l}\text { Awareness of mould } \\
\text { infection in maize and } \\
\text { groundnuts }\end{array}$ & $1=$ Yes, $0=$ Otherwise \\
\hline & Explanatory variables & Categories \\
\hline Education & $\begin{array}{l}\text { Highest education level } \\
\text { reached }\end{array}$ & $\begin{array}{l}1=\text { High school and above, } \\
0=\text { Less than high school }\end{array}$ \\
\hline Age & Respondent's age & $\begin{array}{l}1=35 \text { years old and above, } \\
0=\text { less than } 35 \text { years old }\end{array}$ \\
\hline Income & Household annual income & $\begin{array}{c}1=\text { Above U\$D 66.7 } \\
0=\text { Below U\$D } 66.7\end{array}$ \\
\hline Gender & Gender of respondents & $1=$ Male, $0=$ Female \\
\hline $\begin{array}{l}\text { Marital } \\
\text { status }\end{array}$ & Marital status of respondents & $\begin{array}{l}1=\text { Married, } 0=\text { Single, } \\
\text { divorced or widow }\end{array}$ \\
\hline
\end{tabular}


Table 8 Independent t-test on demographic and socioeconomic characteristics on knowledge of mould infections in stored maize and groundnuts $(n=72)$

\begin{tabular}{lllll}
\hline Variable & $N$ & Mean Scores \pm SD & T & $p$-value \\
\hline Gender & & & 1.366 & $0.024^{*}$ \\
Female & 28 & $1.7273 \pm 0.4506$ & & \\
Male & 44 & $1.5714 \pm 0.5040$ & & \\
Education level & & & -6.295 & $0.000^{* * *}$ \\
Greater than high school & 26 & $1.9231 \pm 0.3147$ & & \\
Less than high school & 46 & $1.8913 \pm 0.2718$ & & \\
Age & & & 1.993 & $0.050^{*}$ \\
Less than 35 years old & 23 & $1.9565 \pm 0.2085$ & & \\
Greater than 35 years old & 49 & $1.9796 \pm 1.9796$ & & \\
Marital Status & & & -3.949 & $0.001^{* *}$ \\
Single, divorced, or widow & 25 & $2.5600 \pm 1.8726$ & & \\
Married & 47 & $2.9787 \pm 1.6874$ & & \\
Household income & & & 2.802 & $0.008^{*}$ \\
Less than 66.7 U\$D & 51 & $1.6275 \pm 0.48829$ & & \\
Greater than 66.7 U\$D & 21 & $1.2857 \pm 0.46291$ & & \\
\hline
\end{tabular}

* Significant different at $p<0.05$, ** Significant different at $p<0.01$, *** Significant different at $p<0.0001$

Several important findings were obtained in this study regarding the effects of demographics and socio economic factors on awareness and knowledge of mould infection in food crops. Education, age, gender, marital status and income level of the farmers had significant positive impact on awareness and knowledge of mould infection in stored maize and groundnuts. Dosman et al. (2001) found that people with higher levels of education were likely to be better informed, and may be more aware of some types of risk of food additives in food than people with less education. Similarly, Baker (2003) found that people with the highest levels of education were more willing to pay for safer food.

The significant difference between men and women with respect to the awareness of mould infection in food crops and how to manage mycotoxin in spoilt food were noted. Female respondents showed greater awareness on mould infection because they were responsible for post harvest handling. Males were less engaged in the postharvest operations. Women in rural areas are responsible for $87 \%$ of the labour used for growing food consumed by households in Tanzania (Ogunlela and Mukhtar 2009). Lin (1995) found that women and fulltime homemakers were most concerned with food safety while Baker (2003) also reported that women had the strongest reaction to low-visibility food safety risk. However, being single, divorced or widow contributed to low level of knowledge among the respondents (Dosman et al. 2001).
Persons with age greater than 35 years who had been farming maize and groundnuts in the past 20 years were more likely to perceive that mould infections had been a problem than people with age less than 35 years. Several explanations for this finding have been posited by Dosman et al. (2001) who said that older individuals are more likely to rate and perceive risks higher than young individuals.

In the present study, respondents with higher income were more knowledgeable on mycotoxins compared to lower income respondents. Level of income increases, the overall perception of the world as a risky place decreases (Jolly et al. 2008). Another study showed that people with better income were likely to have more access to knowledge compared to those with low income status (Dosman et al. 2001).

Our results indicated that higher education level, age and gender were positively related to awareness and knowledge on mould infection. Education and awareness are key factors in mitigating the problems of mycotoxins in developing economies (Strosnider et al. 2006). Awareness is said to be short lived and to be sustainable it must be constantly recharged (Warner and Murt 1984).

Levels of fumonisin contamination determined by this study compare very well with levels reported from other studies on home stored maize in rural areas of Africa. Doko et al. (1996) reported fumonisin contamination of $165 \mu \mathrm{g} /$ $\mathrm{kg}$ and $225 \mu \mathrm{g} / \mathrm{kg}$ for samples of maize from Tanzania. The same authors reported fumonisin levels of $370 \mu \mathrm{g} / \mathrm{kg}$ in maize collected from Botswana, and $135 \mu \mathrm{g} / \mathrm{kg}$ for maize from Malawi. Other studies analysed maize from market outlets which contained this level of contamination compared to home grown maize as reported by Shepherd et al. (1996). High levels of fumonisins (up to $20 \mu \mathrm{g} / \mathrm{kg}$ ) have also been found in maize based food (maize, maize flour and polenta) in Italy (Visconti et al. 1998). Elsewhere, even higher levels of fumonisin contamination have been reported. For example, the results of a survey carried out in China indicated that fifty six per cent of samples (134/240) were found to contain fumonisin $\mathrm{B}_{1}$ at levels ranging from $50-34868 \mu \mathrm{g} / \mathrm{kg}$ (Ueno et al. 1997). Germany reported detection of fumonisins in $27 \%$ of samples (86/317) and levels ranged from 6-7132 $\mu \mathrm{g} / \mathrm{kg}$ (Meister et al. 1996). Continuous monitoring of these mycotoxins is required in order to assure that maize products containing high levels of fumonisins are not consumed by animals and humans.

High aflatoxin level (above $20 \mu \mathrm{g} / \mathrm{kg}$ ) in groundnuts determined in this study, were also reported in other studies (Akano and Atanda, 1990 and Adebanjo et al. 1994). Yamego and Kassamba (1999) reported that seeds of groundnut from Burkina-Faso inoculated with Aspergillus flavus excreted all the four major aflatoxins $\left(B_{1}, B_{2}, G_{1}\right.$ and $G_{2}$ ) which peaked at $170 \mu \mathrm{g} / \mathrm{kg}$ after six days. Another study carried out by Haryadi and Setiastuty (1994) on 
aflatoxin contamination in 30 samples of raw groundnuts collected from various traders, reported that aflatoxin $B_{1}$ was detected in 8 out of 15 samples collected. Aflatoxin levels exceeding $20 \mathrm{ppb}$ must be considered unsatisfactory, while those exceeding $100 \mathrm{ppb}$ must be considered totally unsatisfactory, capable of inducing acute toxic effects in both human and animals.

\section{Conclusion}

We conclude that awareness of mould infection in stored maize and groundnuts was low in the study village. Female farmers were more aware of mould infection food crops compared to male farmers while educated farmers were more aware of mould infections than less educated farmers. Level of awareness on mould infection differed between income groups and marital status.

We recommend that, awareness campaigns should be carried to help raise awareness on aflatoxins. Such campaigns should be streamlined according to gender and income of target populations.

\section{Acknowledgements}

The authors express sincere thanks to all who helped execution of the study especially the staff members of the Department of Crop Science and Horticulture and Development Studies Institute, Sokoine University of Agriculture, Morogoro Tanzania.

\section{Funding}

This work was privately funded by Dr Steven Magembe as part of his PhD program at Sokoine University of Agriculture, Morogoro, Tanzania.

\section{Authors' contribution \\ KSM designed the study, collected and analysed data. MWM, designed the study, supervised field work and revised the manuscript. DPM supervised field work and critically revised the sections on mycotoxins. EEC designed sampling and collection of socio-economic data. All the authors have read and approved the manuscript.}

\section{Competing interests}

The authors declare that they have no competing interests.

\section{Author details}

${ }^{1}$ Development Studies Institute, Sokoine University of Agriculture, Tanzania, P. O. Box 3024, Morogoro, Tanzania. ${ }^{2}$ Department of Crop Science and Horticulture, Sokoine University of Agriculture, P.O. Box 3005, Morogoro, Tanzania.

Received: 4 June 2016 Accepted: 3 August 2016

Published online: 11 August 2016

\section{References}

Abbas HK, Williams WP, Windham GL, Pringle HC, Xie W, Shier WT. Aflatoxin and fumonisin contamination of commercial corn (Zea mays) hybrids in Mississippi. J Agric Food Chem. 2002;50:5246-54.

Adebanjo LO, Idowu AA, Adesanya OO. Mycoflora and mycotoxin production in Nigerian Corn-based Snacks. Mycopathol. 1994;126:183-92.

Akano DA, Atanda OO. The Present level of aflatoxins in Nigerian groundut cake ("kuli kuli"). Lett Appl Microb. 1990;10:187-9.

Amri E, Lenoi S. Aflatoxin and fumonisin contamination of sun-dried sweet potato (ipomoea batatas L.) chips in Kahama District, Tanzania. J Appl Env Microbiol. 2016;4(3):55-62.

Baker GA. Food safety and fear: factors affecting consumer response to food safety risk. Int Food Agribus Manag. 2003;6:1-11.

Bankole S, Schollenbeger M, Drochner W (2006) Mycotoxin contamination of food systems in Sub-Saharan Africa. Bydgoszcz: Soc for Mycotox Res 37pp.
Bhat RV. Human health problems associated with current agricultural food production. Asian Pac J Clinic Nutr. 2008;17:91-4.

Burger HM, Shephard GS, Louw W, Rheeder JP, Gelderblom WCA. The mycotoxin distribution in maize milling fractions under experimental conditions. Int J Food Microb. 2013;165(1):57-64.

Chilaka CA, De Kock S, Phoku JZ, Mwanza M, Egbuta MA, Dutton MF. Fungal and mycotoxin contamination of South African commercial maize. J Food Agric Environ. 2012;10:296-303.

Doko MB, Canet C, Brown N, Sydenham EW. Natural occurrence of fumonisins and zearalenone in cereals and cereal-based foods from Eastern and Southern Africa. J Agric Food Chem. 1996:44:3240-3.

Dosman DM, Adamowicz WL, Hrudey SE. socioeconomic determinants of healthand food safety-related risk perceptions. Risk Anal. 2001;21:307-17.

Haryadi $Y$, Setiastuty $E$ (1994). Characterisation of aflatoxins $B_{1}, B_{2}$ and $G_{2}$ in groundnuts and groundnut products. Proceeding of the $6^{\text {th }}$ International Working Conference on Stored-Product Protection, Canberra, Australia, pp.996-998.

Hatcher L. A step-by-step approach to using the sas system for factor analysis and structural equation modeling. North Carolina: SAS Institute; 1994.

Hell K, Mutegi C. Aflatoxin control and prevention strategies in key crops of SubSaharan Africa. Afr J Microbiol Res. 2011;5:459-66.

Jolly PE, Jiang YE, William O, Awuah RT, Appawu J, Nnedu O. Association between aflatoxin exposure and health characteristics, liver function, hepatitis and malaria infections in Ghanaian. J Nutr Env Med. 2007;16(3):1-16.

Jolly CM, Bayard B, Awuah RT, Fialor SC, Williams JT. Examining the structure of awareness and perceptions of groundnuts aflatoxin among Ghanaian health and agricultural professionals and its influence on their actions. J Socio Econ. 2008:38:280-7.

Kamala A, Kimanya M, Haesaert G, Tiisekwa B, Madege R, Degraeve S, Cyprian D, Meulenaer B. Local post-harvest practices associated with aflatoxin and fumonisin contamination of maize in three agro ecological zones of Tanzania. Food Add Contamin. 2016;33(3):551-9.

Kimanya M, Tiisekwa B, Devlieghere F, Ndomondo-Sigonda M, Van Camp J, Kolsteren P. Co-occurrence of fumonisins with aflatoxins in home stored maize for human consumption in rural villages of Tanzania. Food Add Contamin. 2008;25:1353-64.

Kimanya ME, De Meulenaer B, Roberfroid D, Lachat C, Kolsteren P. Fumonisin exposure through maize in complementary foods is inversely associated with linear growth of infants in Tanzania. Mol Nutr Food Res. 2010;54:1659-67.

Kimanya ME, Meulenaer BD, Tiisekwa B, Ugulluma C, Devliegher F, Van Camp J, Samapundo VS, Kolsteren P. Fumonisins exposure from freshly harvested and stored maize and its relationship with traditional agronomic practices in Rombo District, Tanzania. Food Add Contamin. 2009:26:199-1208.

Kimanya ME, Shirima CP, Magoha H, Shewiyo DH, De Meulenaer B, Kolsteren P, Gong YY. Co-exposures of aflatoxins with deoxynivalenol and fumonisins from maize based complementary foods in Rombo, Northern Tanzania. Food Contr. 2014;41:76-81

Kumar V, Basu MS, Rajendran TP. Mycotoxin research and mycoflora in some commercially important agricultural commodities. Crop Prot. 2008;27:891-905.

Kumar GDS, Popat MN. Farmer's perceptions, knowledge and management of aflatoxins in groundnuts (Arachis hypogaea L.) in India. Crop Prot. 2010;29:1534-41.

Lin CTJ. Demographic and socioeconomic influences on the importance of food safety in food shopping. Agric Resour Econ Rev. 1995;24:190-8.

Magoha H, Kimanya M, De Meulenaer B, Roberfroid D, Lachat C, Kolsteren P. Risk of dietary exposure to aflatoxins and fumonisins in infants less than 6 months of age in Rombo, Northern Tanzania. Mater Child Nutr. 2016;12(13):516-27.

Meister U, Symmank H, Dahlke H. Untersuchung und Bewertung der Fumonisin contamination von einheimischen und importiertem Getreide. Zeitung fur Lebensmittel Untersuchung und Forschung. 1996;203:528-33.

Ogunlela N, Mukhtar H. Gender issues in agriculture and rural development in Nigeria. Hum Soc Sci J. 2009;4:19-30.

O'Riordan MJ, Wilkinson MG. A survey of the incidence and level of aflatoxin contamination in a range of imported spice preparations on the Irish retail market. Food Chem. 2008;107:1429-35

Okello DK, Kaaya AN, Bisikwa J, Were M, Olota HK. Management of Aflatoxins in groundnut: manual for farmers, processors, traders and consumers in Uganda. National Agricultural Research Organisation: Makerere University; 2010. p. 27 pp.

Shephard GS, Theil PG, Stockenström S, Sydenham EW. Worldwide survey of fumonisin contamination of corn and corn-based products. J AOAC Int. 1996;79:671-87.

Strosnider H, Azziz-Baumgartner E, Marianne B, Bhat RV, Breiman R, Brune MN. Public health strategies for reducing aflatoxin exposure in developing countries. Env Health Persp. 2006;114:1898-903. 
Suleiman R, Rosentrater K, Bern C. Effects of Deterioration Parameters on Storage of Maize. Rev J Nat Sci Res. 2013;3(9):147-65.

Truckess MW, Stack ME, Nesheim S, Page SW, Albert RH, Hansen TJ. Immunoaffinity column coupled with solution fluorometry or liquid chromatography post column derivatization for determination of aflatoxins in corn, groundnuts and groundnut butter: collaborative study. J O Analyt Chem. 1991;74(1):81-8.

Ueno Y, lijima K, Wang SD, Sugiura Y, Sekijima M, Tanaka T, Chen C, Yu SZ. Fumonisins as a possible contributory risk for primary liver cancer a 3 year study of corn harvested in Haimen, China, by HPLC and ELISA. Food Chem Toxicol. 1997;35:1143-50.

Visconti A, Avantaggiato G, Solfrizzo M (1998). Biomaker to display the ingestion of fumonisins through contaminated diet. Analysis of sphinganine/ sphingosine ratio in biological samples. In: Marengo, G and Pastoni, F. (Eds), Proceedings of Sixth International Symposium on Microbiology of Food and Cosmetics in Europe. pp. 260-280.

WHO (2006) Mycotoxins in African foods: implications to food safety and health AFRO Food Safety Newsletter, World Health Organization.

Wu F. Mycotoxin reduction in Bt corn: potential economic, health, and regulatory impacts. Transgenic Res. 2006;15(3):277-89.

Yameogo RT, Kassamba B. Aspergillus favus and aflatoxins on tropical seeds used for snacks, Arachi hypogaea, Balanites aegyptiaca and Sclerocarya birrea. Trop Sci. 1999:39:46-9.

\section{Submit your manuscript to a SpringerOpen ${ }^{\odot}$ journal and benefit from:}

- Convenient online submission

- Rigorous peer review

- Immediate publication on acceptance

- Open access: articles freely available online

High visibility within the field

Retaining the copyright to your article

Submit your next manuscript at $\gg$ springeropen.com 